\title{
Tingiv kõneviis eesti B1- ja B2- taseme kirjalikus õppijakeeles kui keeleoskuse arengu näitaja
}

\author{
MARE KITSNIK \\ Tallinna Ülikool
}

Ülevaade. Kirjeldan artiklis tingiva kõneviisi kasutamist eesti keele kui teise keele täiskasvanud õppijate B1- ja B2-taseme kirjalikes eksamitekstides. Artikli aluseks olnud uuring on osa suuremast uuringust, mille eesmärk on luua Euroopa keeleõppe raamdokumendi (CEFR 2007) B1- ja B2-keeleoskustaseme funktsionaalsete keelekirjelduste juurde lingvistilised kirjeldused. Selleks on kavas leida mõlemal tasemel tüüpiliselt kasutatavad lingvistilised kategooriad, kirjeldada nende kasutuse sagedust, analüüsida kategooriate keerukust ja täpsust (Housen jt 2012), leida nende seosed suhtlusfunktsioonidega ning tuua välja tasemeid eristavad deskriptorid.

Et tingiva kõneviisi kasutussagedus on B2-tasemel võrreldes B1-tasemega palju suurem (Kitsnik 2014), on tingiv kõneviis üks B1- ja B2-taset eristav kategooria, mis vajab detailsemat uurimist. Artiklis kajastatava uuringu tulemused näitavad, et nii B1- kui ka B2-tasemel kasutatakse ainult tingiva kõneviisi isikulise tegumoe olevikuvorme. B1-tasemel esineb tingiv kõneviis koos kaheksa eri verbiga, neist sagedamini kahe verbiga, milleks on tahtma ja saama. B2-tasemel esineb tingiv kõneviis 23 eri verbiga, neist sagedamini kuue verbiga: tahtma, olema, võima, pidama, soovima, soovitama.

B2-tasemel kasutatakse tingivat kõneviisi lisaks B1-tasemel esinenud ainsuse esimese ja kolmanda pöörde vormidele ka teistes morfoloogilistes vormides ning lisaks B1-tasemel esinenud 
konstruktsioonile "verb tingivas kõneviisis + infinitiiv" ka teistes konstruktsioonides (objektiga, öeldistäitega ja liitlause pea- ning kõrvallauses). Suhtlusfunktsioonidest kasutatakse tingivat kõneviisi nii B1- kui ka B2-tasemel peamiselt viisakuse väljendamiseks. Keeleline täpsus suureneb B2-tasemel neis konstruktsioonides, mis on kasutusel ka B1-tasemel.

Võtmesõnad: teise keele omandamine; morfosüntaks; leksika; sagedus; täpsus; keerukus

\section{Sissejuhatus}

Esimese keele (K1) ja teise keele (K2) omandamine on keerukad protsessid, mida on palju uuritud. Teise keele puhul on teadlased peamiselt keskendunud sõnavara ja grammatiliste struktuuride omandamise seaduspärasuste otsimisele. Seejuures on võrreldud ka teise keele ja esimese keele omandamist ning analüüsitud keeleomandamise universaalseid põhimõtteid ja individuaalseid eripärasid. Tänapäeval on üldiselt tunnustatud keeleoskuse arengu kirjeldamine kolme dimensiooni, s.o keerukuse (ingl complexity), täpsuse (accuracy) ja sujuvuse (fluency) ehk nn CAF-triaadi abil (Housen jt 2012). Keerukusena vaadeldakse seejuures tavaliselt õppijakeele sõnavara ja keelestruktuuride sagedust ning varieeruvust. Täpsuseks peetakse õppijate sõnavara ja struktuuride sarnasust normile (emakeelekõnelejate keelekasutusele). Sujuvus on (tavaliselt suulise) õppijakeele sarnasus emakeelekõnelejate keelekasutusega kiiruse, pauside, paranduste jmt poolest.

Nüüd on K2 uurijail uus väljakutse: lingvistiliste kirjelduste loomine Euroopa keeleõppe raamdokumendi (CEFR 2007) tasemekirjelduste juurde. Raamdokument on kogu Euroopa teise keele õppe ja keeleoskuse hindamise korraldamise alus. Selles on esitatud kuue keeleoskustaseme, s.o A1, A2 (algaja keelekasutaja), B1, B2 (iseseisev keelekasutaja) ja C1, C2 (vilunud keelekasutaja) funktsionaalsed kirjeldused, mis näitavad, milliste suuliste ja kirjalike suhtlussituatsioonidega vastaval tasemel olev isik toime tuleb (Bachman \& Palmer 2010). Keeleõppe arendajad 
ja keeleoskuse hindamise asjatundjad vajavad lisaks funktsionaalsetele kirjeldustele tasemepõhiseid lingvistilisi kirjeldusi ehk infot selle kohta, millist leksikat ja grammatilisi konstruktsioone keeleomandajad eri tasemetel eri suhtlusfunktsioonide väljendamiseks kasutavad ning kui korrektselt nad seda teevad. Kui raamdokument on loodud paljude riikide asjatundjate koostöös ja selle sisu on universaalne, siis lingvistilistes kirjeldustes on universaalsete joonte kõrval nii palju keelespetsiifilist, et nende loomine peab jääma iga keele ekspertide tööks.

Mitmete keelte kohta on lingvistilised kirjeldused loodud või loomisel. ${ }^{1}$ Tuntuim on "English Profile" mis põhineb mahukate keelekorpuste (Cambridge Learner Corpus - mitusada tuhat inglise keele kui teise keele eri rahvustest omandajate eksamitööd) ja muude allikate (eksamiülesanded, õppematerjalid jm) uurimisel. "English Profile” koosneb kahest osast: "English Vocabulary Profile"2 ja "English Grammar Profile"3 - neis on vastavalt kirjeldatud, millist sõnavara (sh mis tähenduses, millistes ühendites jm) ja grammatilisi struktuure (sh mis funktsioonides) keeleomandajad tasemetel A1-C2 kasutavad. Eesti keelele lähedastest keeltest on õppijakeele tasemepõhiseid lingvistilisi uuringuid tehtud üsna palju soome keele kohta (nt projektid CEFLING ${ }^{4}$ ja TOPLING ${ }^{5}$ ).

Eesti keele kohta on valminud raamdokumendipõhised funktsionaalsed tasemekirjeldused: kõigepealt kaheksa autori koostöös loodud B1- ja B2-taseme käsiraamat (Hausenberg jt 2008) ning selle eeskujul A1-taseme käsiraamat, A2-taseme käsiraamat (Ilves 2008; 2010) ja C1-taseme käsiraamat (Kerge 2008). Nendes käsiraamatutes on esitatud ka lühikesed tasemepõhised lingvistilised kirjeldused. Palju näiteid suhtlusfunktsioonide väljendamise kohta on toodud mahukas käsiraamatus "Eesti keele suhtluslävi" (Ehala jt 1997), nõuandeid

\footnotetext{
1 http://www.coe.int/t/dg4/linguistic/DNR_EN.asp\#P66_9442 (10.7.2015).

2 http://www.englishprofile.org/wordlists (10.7.2015).

3 http://www.englishprofile.org/english-grammar-profile/grammar (10.7.2015).

4 https://www.jyu.fi/hum/laitokset/kielet/tutkimus/hankkeet/paattyneet-hankkeet/ cefling (10.7.2015).

5 https://www.jyu.fi/hum/laitokset/kielet/tutkimus/hankkeet/topling (10.7.2015).
} 
keelestruktuuride ja sõnavara kasutamise kohta leiab ülevaadetest "Eesti süntaks keeleõppe praktikule: käsiraamat" (Kerge 2001) ja "Keelehärm: eesti keele probleemseid piirkondi” (Metslang jt 2003). Kõigis eespool nimetatud käsiraamatutes esitatud lingvistilised kirjeldused põhinevad vaid autorite kogemusel, intuitsioonil ja mõnel üksikküsimusi käsitleval uuringul. Keeleoskustasemete põhjalikumad, teaduslikel uuringutel põhinevad lingvistilised kirjeldused meil puuduvad.

Eesti õppijakeele uurimisel on seni keskendutud vaid kirjalike tekstide keelelisele täpsusele (Maisla 2014; Pool 2007; Pastuhhova 2005; Ratassepp 2007; Kitsnik 2007 jpt; vt ka Pool 2010). Viimasel ajal on alustatud kirjaliku õppijakeele keerukuse (Eslon 2011; 2012; 2013; 2014) ja sujuvuse uurimist (Pastuhhova 2011), kuid mitte tasemepõhiselt. Keelenähtuste ilmumist esimese keele suulisse kasutusse on vaadelnud eesti lapsekeele uurijad (vt nt Argus 2004; 2007; 2012 jt). Uuritud on emakeeleõppijate keelekasutuse keerukust (Kerge jt 2014a; 2014b).

Käesoleva artikli aluseks olnud tingiva kõneviisi uuring moodustab osa kirjaliku õppijakeele üldisemast uuringust, milles võrdlen B1- ja B2-keeleoskustasemete lingvistilist sisu ja selle seoseid suhtlusfunktsioonidega ning otsin tasemeid eristavaid deskriptoreid. B-taseme olen uurimiseks valinud selle olulisuse tõttu keeleoskuse arengus - alates sellest tasemest saab inimene hakkama iseseisva suhtlemisega. Samas on B1- ja B2-tase siiski väga erinevad. Kui B1-tasemel tuleb inimene toime isiklike asjade korraldamisega, siis B2-tasemel lisandub ühiskondlik mõõde: saadakse aru meediast, suudetakse suhelda keerukamas tööalases keeles jmt. B1- ja B2-tase on olulised ka riiklikust seisukohast: B1-tase on nõutav kodakondsuse taotlemiseks, B2-tase kõrgkoolis õppimiseks ning paljudes riigiametites töötamiseks.

B1- ja B2-taseme lingvistilist sisu uurides olen varem jälginud verbivormide esinemist kummalgi tasemel (Kitsnik 2014) ning välja selgitanud, et üheks vastavaid tasemeid eristavaks deskriptoriks on tingiva kõneviisi kasutussagedus. Käesoleva artikli aluseks olnud uuringus jälgisin tingiva kõneviisi esinemist B1- ja B2-tasemel detailsemalt. 


\section{Keeleoskuse lingvistilise arengu uurimisest}

Raamdokumendi tasemete kirjeldused näitavad keeleomandamise arengut minimaalsest oskusest ehk A1-tasemest kuni haritud emakeelekõnelejaga sarnase oskuse ehk C2-tasemeni. Arengu käigus muutuvad järjest keerukamaks suhtlusülesanded, millega keeleomandaja toime tuleb: näiteks A1-tasemel "oskab isik kirjutada lühikest ja lihtsat postkaarditeksti”, aga C2-tasemel "oskab end isiklikus kirjavahetuses selgelt ja täpselt väljendada, kasutades keelt paindlikult ja mõjusalt; isik valdab emotsionaalset ja vihjelist keelepruuki, oskab teha nalja" (CEFR 2007: 87). Keeleõpetamise ja -hindamisega tegelejad vajavad infot ka selle kohta, kuidas kaasneb funktsionaalse arenguga lingvistiline areng: millist sõnavara ja milliseid keelestruktuure eri keeleoskustasemete suhtlusülesannete täitmiseks tüüpiliselt kasutatakse ning kui keerukalt, täpselt ja sujuvalt seda tehakse. Sedalaadi teave aitab kaasa ka keeleomandamise üldiste seaduspärasuste paremale mõistmisele. Aga mil määral on selliseid kirjeldusi üldse võimalik koostada?

Keelenähtuste omandamise järjekorra kui keeleoskuse arengu näitaja suhtes on uurijad eri arvamusel. Mõned teadlased on seisukohal, et keelenähtused omandatakse ettemääratud järjestuses. Näiteks Stephen Krasheni (1982) teooria kohaselt omandavad kõik inimesed keelekeskkonnas keelt kasutades grammatilised struktuurid samas ehk loomulikus järjestuses. Manfred Pienemanni (1998) järgi läbivad kõik keeleomandajad oma arengus sarnased etapid, liikudes struktuure omandades lihtsamatest keerukamate suunas. Eri keeltes võib omandatavate struktuuride järjestus erineda, sõltudes struktuuri raskusest konkreetses keeles. John A. Hawkins ja Paula Buttery on samuti arvanud, et struktuuride omandamise järjekord samas keeles on kõigil õppijail sarnane, sõltudes struktuuri keerukusest ning esinemissagedusest keeles (sagedamad ja lihtsamad omandatakse varem, kergemini ja korrektsemalt, harvemad ja keerukamad hiljem, aeglasemalt ja ebakorrektsemalt) (Hawkins 2004; Hawkins \& Buttery 2009). 
Teiste uurijate hinnangul võib keelenähtuste omandamise järjekord olla erisugune, sõltudes vastava sõna või struktuuri sagedusest sisendis ja õppija vajadusest seda kasutada (Long 1996; Larsen-Freeman 1997; 2011 jt). Diane Larsen-Freeman on võrrelnud teise keele omandamist kaosest korra tekkimise protsessiga - piisava sisendi korral toimub keeleomandamine suhtluspartneritega kohanedes ja suhtluses kasutatavate keelemallide eeskujul iseorganiseeruvalt. Keeleomandamise protsess ei ole Larsen-Freemani arvates mitte lineaarne, vaid kompleksne ning seega ei ole võimalik täpselt ennustada, mis järjekorras ja mil määral õppija mingid keelenähtused omandab. Keelestruktuuride omandamist mõjutab ka õppijate esimene keel. Oma emakeelest tuttavaid struktuure omandatakse kiiremini ja kergemini (Ringbom 2007; Jarvis \& Odlin 2000; MacWhinney 2004; Kaivapalu 2005 jt).

Küsitav on ka struktuuri omandatuse hindamine, sest ühtegi struktuuri ei omandata kohe täielikult. Rod Ellise arvates on kõigile keeleõppijaile iseloomulikud ühised grammatilise struktuuri omandamise etapid: 1) uue struktuuri mittekasutamine, 2) uue struktuuri kasutamise alustamine, 3) uue struktuuri üleüldistatud ehk liigne kasutamine, 4) segastruktuuride kasutamine mõnikord, 5) uue struktuuri korrektne kasutamine. Seejuures võib teatud aja möödudes toimuda langus mõnele eelmisele tasemele (Ellis 2000).

Keeleoskustasemete lingvistiliste kirjelduste koostamiseks on vaja leida üldised seaduspärasused keelenähtuste ilmumisel õppijakeelde. Seejuures ei piisa vaid ilmumise fikseerimisest, vaid iga nähtust on vaja uurida detailsemalt. Seda on võimalik teha CAF-triaadi dimensioonide keerukus, täpsus ja sujuvus abil.

Lingvistiline keerukus on määratud keeleüksuste vormidega, tähendustega ning vormi ja tähenduse üks-ühese kattuvuse määraga. Keerukus jaguneb süsteemi keerukuseks (mille määrab leksika) ning struktuuri keerukuseks (mille määravad morfoloogia ja süntaks) (Bulté \& Housen 2012). Keerukus suureneb eri morfoloogiliste vormide hulga kasvuga, nendega seotud süntaktiliste konstruktsioonide ja semantiliste omaduste hulga suurenemisega ning kasutusala laienemisega (Hawkins 
2004). Täpsuseks peetakse keelekasutuse vastavust normile. CAF-i uurimustes peetakse normiks emakeelekõnelejate keelekasutust, mida teised suhtluses osalejad aktsepteerivad. Seega on täpsus keelekollektiivi, mitte keelekorralduse norm. (Ellis 2008; Pallotti 2009) Sujuvus on sarnasus emakeelekõneleja kasutusega mingis ajaühikus produtseeritud keeleühikute hulga, katkestuste arvu ja pikkuse, kordamiste hulga, eneseparanduste hulga jmt poolest (Skehan 2003). Seda on enamasti uuritud suulistes tekstides.

Õppijakeele keerukust, täpsust ja sujuvust on uuritud palju nii eraldi (Ellis 2008; Pallotti 2009; Housen \& Kuiken 2009; Skehan 2009 jt) kui ka vastastikuses koosmõjus (Larsen-Freeman 2006; 2009; Spoelman \& Verspoor 2010; Norris \& Ortega 2009 jt). Praeguste arusaamade järgi võib öelda, et need kolm dimensiooni ei arene kindlasti sõltumatult ja sirgjooneliselt, vaid mõjutavad üksteist mitmel viisil. Seejuures on vastastikune mõju mõnikord toetav (ühe dimensiooni areng toob kaasa ka teise dimensiooni arengu), mõnikord võistlev (ühe dimensiooni areng pidurdab teise dimensiooni arengut) (Housen jt 2012). Näiteks võib keelekasutuse keerukuse kasv vähendada täpsust või täpsuse kasv vähendada sujuvust (Skehan 1998).

Senistes keeleoskustasemete lingvistilise sisu uurimustes on keskendutud nii keelenähtuste ilmumisele õppijakeelde kui ka CAF-triaadi dimensioonide arengu vaatlemisele (Alanen jt 2010; Gunnarsson 2012; Kuiken \& Vedder 2012; Martin jt 2010; Salamoura \& Saville 2010; Spoelmann \& Verspoor 2010 jpt). Uurimustulemusi on arvestatud keeleoskustasemete lingvistiliste kirjelduste koostamisel (nt "English Profile", "Profile deutsch"7), kuid tasemepõhistel lingvistilistel kirjeldustel on veel palju arenguruumi. Jan H. Hulstijni (2014) hinnangul oleks vaja eri keelte tasemepõhiste sõnavara- ja keelestruktuuride kirjelduste osas saavutada suurem konsensus. Samuti on Hulstijni arvates probleeme lingvistiliste nähtuste paigutamisega teatud tasemele - sageli ei ole see nii üheselt määratletav. Ka Mick O’Donnelli (2013) hinnangul pole paljude

$6 \quad$ http://www.englishprofile.org (10.7.2015).

7 https://www.goethe.de/de/spr/unt/kum/prd.html (10.7.2015). 
nähtuste kohta võimalik öelda, mis tasemele need täpselt kuuluvad, vaid pigem saab kirjeldada keeleüksuste omandamise järjekorda. Edasist uurimist vajab ka keeleoskustasemete funktsionaalne sisu - tuleb leida vastused küsimustele, kas kõik keeleomandajad läbivad tasemed samas järjekorras või on võimalikud ka teatud aspektide vahelejätmised, mil määral erinevad keelekeskkonnas ja õppeklassis omandatud keeleoskus, mille poolest sarnanevad noorukite ja täiskasvanute keeleoskus, kuidas mõjutab mingi keeleoskustaseme saavutamist isiku üldine vaimne võimekus jpm (vt nt North 2014; Hulstijn 2011).

\section{Tingiv kõneviis eesti B1- ja B2-taseme kirjalikus õppijakeeles}

Uuringus jälgisin õppijakeele arengut tingiva kõneviisi kasutamise osas. Otsisin B1- ja B2-taseme kirjaliku õppijakeele põhjal vastuseid järgmistele kumbagi taset puudutavatele küsimustele.

- Milliseid tingiva kõneviisi morfoloogilisi vorme kasutatakse?

- Millistes süntaktilistes konstruktsioonides tingiv kõneviis esineb?

- Millised verbid esinevad tingivas kõneviisis?

- Milliseid suhtlusfunktsioone väljendatakse tingiva kõneviisi abil?

Võrdlesin saadud tulemuste põhjal tingiva kõneviisi sagedust, keerukust ja täpsust B1- ja B2-taseme õppijakeeles ning tõin välja tasemeid eristavad tingiva kõneviisi kasutuse deskriptorid.

\subsection{Tingiv kõneviis eesti keeles}

Tingiva kõneviisi morfoloogilised vormid esinevad eesti keeles isikulise ja umbisikulise tegumoe olevikus ja minevikus. Isikulise tegumoe vormidel on nii pikad ehk pöördelõpuga kui ka lühikesed ehk pöördelõputa kujud. Tingiva kõneviisi tunnusel on kaks kuju: -ksi- (kui järgneb 
pöördetunnus, nt teeksin, oleksin teinud) ja -ks (sõna lõpus, nt teeks, oleks teinud). ${ }^{8}$

Tingiva kõneviisi süntaktilistest konstruktsioonidest otsisin õppijakeelest järgmisi (vt tabel 1$)^{9}$.

TABEL 1. Tingiva kõneviisi süntaktilisi konstruktsioone eesti keeles

\begin{tabular}{|l|l|}
\hline Süntaktiline konstruktsioon & Näide \\
\hline VERB $_{\text {COND }}+$ INFINITIIV & tahaksin jalutada \\
\hline $\mathrm{VERB}_{\mathrm{COND}}+$ OBJEKT & tahaksin kooki \\
\hline $\mathrm{VERB}_{\mathrm{COND}}+$ ÖELDISTÄIDE & (kui ta) oleks minu sõber \\
\hline VERB $_{\text {COND }}+$ MÄÄRUS & ütleksin talle \\
\hline PEALAUSE + KÕRVALLAUSE (VERB $_{\mathrm{COND}}$ ) & tahan, et ta tuleks \\
\hline PEALAUSE (VERB & COND $)+$ KÕRVALLAUSE (VERB \\
\hline PEAND $)$ & tahaksin, et ta tuleks \\
\hline
\end{tabular}

Tingiva kõneviisi suhtlusfunktsioone on uuritud eesti kirjakeeles ja emakeelekõnelejate suulises keeles (Metslang 1999; R. \& K. Pajusalu 2004; 2010; R. Pajusalu 2014; Teemets 2010; Rüütmaa 2014; Plado 2013) ning lapsekeeles (Pajusalu jt 2011) - järgnevalt esitan tingiva kõneviisi peamised suhtlusfunktsioonid (vt tabel 2) nende allikate põhjal. Näitelaused olen moodustanud ise.

TABEL 2. Tingiva kõneviisi sagedamaid suhtlusfunktsioone eesti keeles

\begin{tabular}{|l|l|}
\hline Suhtlusfunktsioon & Näitelause \\
\hline teatud tingimustel toimuda võiva või & Kui ta mind kinno kutsuks, siis ma \\
toimuda võinud tegevuse kirjeldamine & läheks. \\
& $\begin{array}{l}\text { Kui ta oleks mind kinno kutsunud, } \\
\text { siis ma oleks läinud. }\end{array}$ \\
\hline soovi väljendamine & Kutsuks ta mind ometi kinno! \\
\hline
\end{tabular}

8 http://www.eki.ee/books/ekk09 (10.7.2015).

$9 \quad$ Koostanud käesoleva artikli autor. 


\begin{tabular}{|l|l|}
\hline kahetsuse väljendamine & $\begin{array}{l}\text { Oleks ma ometi sellest varem kuul- } \\
n u d !\end{array}$ \\
\hline $\begin{array}{l}\text { eri tüüpi ebakindluse ja ebamäärasuse } \\
\text { väljendamine, sageli modaalverbidega } \\
\text { peaks, võiks, tahaks }\end{array}$ & $\begin{array}{l}\text { Tahaks midagi head. } \\
\text { Võiksin vähem arvutis istuda. } \\
\text { Peaks talle külla minema. }\end{array}$ \\
\hline viisakuse väljendamine & $\begin{array}{l}\text { Kas sa saaksid mulle pastakat } \\
\text { laenata? } \\
\text { Ma sooviks öelda, et ma ei saa tulla. }\end{array}$ \\
\hline $\begin{array}{l}\text { kaudse käsu, palve, soovi vmt } \\
\text { vormistamine et-kõrvallausega }\end{array}$ & $\begin{array}{l}\text { Ta käskis, et ma selle kirja ära } \\
\text { viskaksin. }\end{array}$ \\
\hline võrdluse vormistamine nagu-kõrval- & $\begin{array}{l}\text { Ta naeratas, nagu teaks rohkem kui } \\
\text { räägib. }\end{array}$ \\
\hline lausega &
\end{tabular}

Tingiva kõneviisi kasutamist eesti õppijakeeles pole eraldi uuritud. Euroopa keeleõppe raamdokumendi alusel koostatud B1- ja B2-taseme käsiraamatus on öeldud: "Põhilised kõneviisid (sh tingiv) omandatakse juba A-tasemel. B2-tasemel omandatakse ka kõneviiside komplitseeritumaid rakendusviise, nt osatakse kasutada tingivat kõneviisi käsu leevendamiseks: Kas sa saaksid mind natuke aidata? --- Kaudset käsku või soovi annab põimlauses edasi tingiv kõneviis ja seda tüüpi kõrvallaused tuleb B-tasemel omandada alternatiivi puudumise pärast, nt Isa ütles, et ma tooksin poest leiba" (Hausenberg jt 2008). Käsiraamatus "Eesti süntaks keeleõppe praktikule" (Kerge 2001) on öeldud: "Otsese palve ja soovi vormistab kõrvallause tingiv kõneviis: Ma palun, et te läheks sinna enne kuut. Soovime, et elaksite teise viiskümmend aastat niisama õnnelikult. Annan edasi nende soovi, et te tooks kõik materjalid kaasa".

Suhtlusfunktsioonide kohta on B1- ja B2-taseme käsiraamatus öeldud, et "B1-tasemel oskab isik järgida peamisi viisakunõudeid, ent piiratud keelevahendite tõttu ei taju kõneleja kohati sobivat formaalsuse-informaalsuse vahekorda ning tema keelevahendite valik ei pruugi kohati vastata olukorrale, nt kasutab ta ametiasutuses liiga familiaarset pöördumist või väljendub sõprade seltskonnas rõhutatud viisakusega. B2-tasemel väljendub keelekasutaja selgelt, viisakalt ja kindlalt nii vabas 
kui ametlikus registris, saab hakkama viisakusvestlustega ning suudab igasuguses suhtlusolukorras vestelda, oma seisukohti avaldada ja põhjendada. Samuti orienteerub ta asjaajamiseks vajalikes tekstitüüpides ja järgib viisakat vormistusviisi” (Hausenberg jt 2008).

\subsection{Uurimismaterjal ja -meetod}

Uurimismaterjalina kasutasin täiskasvanute eestikeele riikliku B1-taseme ja B2-taseme eksami kirjutamisosa tekste. Eksamitekstid on kogutud eesti vahekeele korpusesse (edaspidi $\mathrm{EVKK}^{10}$ ), mille põhjal olen koostanud kaks alamkorpust: B1-taseme korpus (24 624 sõnet) ja B2-taseme korpus (21 783 sõnet). B1-taseme korpuses esinevad järgmised tekstitüübid: teade (umbes 50 sõna), jutt etteantud teemal (umbes 100 sõna), isiklik kiri (umbes 100 sõna). B2-taseme korpuse tekstitüüpideks on poolametlik kiri (umbes 140 sõna), mitteametlik kiri (umbes 140 sõna), arutlus (umbes 180 sõna), lähteandmetele toetuv kokkuvõte koos kommentaariga (umbes 180 sõna). Uuringus kasutasin tekste, mille sooritusprotsent oli 60-95.60\% on vastava taseme eksami sooritamise alampiir. Maksimumpunktid saanud tööd jätsin uurimismaterjali hulgast välja, arvestades asjaolu, et nende autorite keeletase võib olla vastaval (B1 või B2) eksamil nõutust kõrgem.

B1 - ja B2-taseme tekstitüüpide erinevus võib tekitada küsimuse, kas need on võrreldavad. Olen lähtunud arusaamast, et tekstitüüp on üks keeleoskustaseme omadustest: funktsionaalsetes tasemekirjeldustes on määratletud, milliste tekstitüüpidega antud keeleoskustasemel keelekasutaja toime tuleb (CEFR 2007: 97-105) ning seega peab ta valdama ka sellistes tekstides vajalikke vorme ja leksikat. Uurimused on näidanud, et ainult ülesande keerukus ei too kaasa süntaktiliselt keerukamat ega leksikaalselt varieeruvamat keelekasutust, kui isik selleks valmis pole (Kuiken \& Vedder 2012). Mitme eri tekstitüübi kasutamine ühe taseme uurimisel vähendab samuti ühe tekstitüübi mõju uurimistulemustele. Ma ei ole arvestanud tekstiautorite taustainfoga (emakeel, haridus,

10 http://evkk.tlu.ee (29.4.2014). 
vanus jmt), kuna minu uurimuse eesmärk on kirjeldada tasemepõhist keelekasutust üldiselt, arvestamata alarühmadele iseloomulikku.

Uurimismeetodina kasutasin korpusest tulenevat (ingl corpus-driven) lähenemist, mille puhul analüüsitakse korpuseainest ilma eelneva hüpoteesita. Uurimuse esimeses etapis moodustasin kummastki korpusest programmi Simple Concordancer ${ }^{11}$ abil verbivormide sagedusloendi. Seejärel valisin sagedusloendist välja tingivas kõneviisis verbivormid (arvestades morfoloogiliste tunnuste esinemist) ja rühmitasin need verbide kaupa. Edasi leidsin sama programmi abil iga vormi konkordantsid ning tegin nende põhjal kokkuvõtted tingiva kõneviisi morfoloogiliste vormide esinemisest, tingiva kõneviisi süntaktiliste konstruktsioonide esinemisest, tingivas kõneviisis esinevatest verbidest ja tingiva kõneviisi kaudu väljendatavatest suhtlusfunktsioonidest kummalgi tasemel.

Kokkuvõtteid tehes arvestasin nähtusi alates viiest esinemiskorrast. Tingiva kõneviisi morfoloogiliseks vormiks lugesin verbivormi, milles esineb tingiva kõneviisi tunnus. Tingiva kõneviisi süntaktiliseks konstruktsiooniks pidasin tingiva kõneviisi morfoloogilist vormi koos tema otsese laiendiga (nt verb tingivas kõneviisis + infinitiivivorm, verb tingivas kõneviisis + kõrvallause jmt). Tingiva kõneviisi suhtlusfunktsiooniks pidasin tingiva kõneviisi abil edasi antavat tähendust, näiteks viisakus, ebakindlus vm. Täpne on konstruktsioon, mis on korrektne nii vormiliselt (konstruktsiooni ulatuses) kui ka sisuliselt (leksikaalselt ja funktsionaalselt). Lisaks kvantitatiivsetele andmetele toon ka tüüpilisi kasutusnäiteid.

Tulemuste põhjal võrdlesin B1- ja B2-taseme tingiva kõneviisi kasutamise sageduse, keerukuse ja täpsuse arengut keeleoskustaseme kasvades (vt tabel 3) ning tõin välja tasemeid eristavad tingiva kõneviisi kasutuse deskriptorid.

11 http://softadvice.informer.com/Simple_Concordance_Programme.html (10.7.2015). 
TABEL 3. Opppijakeele keerukuse ja täpsuse hindamise alused

\begin{tabular}{|c|c|c|}
\hline Uuritav nähtus & $\begin{array}{c}\text { CAF-triaadi } \\
\text { mõiste }\end{array}$ & $\begin{array}{c}\text { Hinnang uuritavale } \\
\text { nähtusele }\end{array}$ \\
\hline $\begin{array}{l}\text { tingiva kõneviisi eri } \\
\text { morfoloogiliste vormide } \\
\text { esinemissagedus }\end{array}$ & \multirow{4}{*}{ keerukus } & \multirow{2}{*}{$\begin{array}{l}\text { sageduse kasv näitab } \\
\text { õppijakeele keerukuse } \\
\text { suurenemist }\end{array}$} \\
\hline $\begin{array}{l}\text { tingiva kõneviisi eri } \\
\text { süntaktiliste konstruktsioonide } \\
\text { esinemissagedus }\end{array}$ & & \\
\hline $\begin{array}{l}\text { eri verbide tingivas kõneviisis } \\
\text { esinemise sagedus }\end{array}$ & & $\begin{array}{l}\text { verbide arvu kasv näitab } \\
\text { opppijakeele keerukuse } \\
\text { suurenemist }\end{array}$ \\
\hline $\begin{array}{l}\text { tingiva kõneviisi abil väljendatud } \\
\text { suhtlusfunktsioonide } \\
\text { esinemissagedus }\end{array}$ & & $\begin{array}{l}\text { funktsioonide arvu } \\
\text { kasv näitab õppijakeele } \\
\text { keerukuse suurenemist }\end{array}$ \\
\hline $\begin{array}{l}\text { vormiliselt (morfoloogiline vorm, } \\
\text { süntaktiline konstruktsioon) } \\
\text { ja sisuliselt (suhtlusfunktsioon, } \\
\text { leksika) korrektsete juhtude } \\
\text { esinemise osakaal kõigist } \\
\text { esinemisjuhtudest }\end{array}$ & täpsus & $\begin{array}{l}\text { korrektsete juhtude } \\
\text { osakaalu kasv näitab } \\
\text { õppijakeele täpsuse } \\
\text { suurenemist }\end{array}$ \\
\hline
\end{tabular}

\section{Uurimistulemused}

\subsection{Tingiva kõneviisi morfoloogilised vormid ja süntaktilised konstruktsioonid B1- ja B2-taseme õppijakeeles}

Kõigepealt jälgisin morfoloogiliste vormide ja süntaktiliste konstruktsioonide esinemist kummalgi tasemel. Tingiva kõneviisi esinemisjuhtude kokkuvõte B1-tasemel on esitatud tabelis 4 ja B2-taseme esinemisjuhtude kokkuvõte tabelis 5 . Tabelite read näitavad morfoloogiliste vormide esinemissagedust ning veerud süntaktiliste konstruktsioonide esinemissagedust. Morfoloogiliste vormide puhul olen eraldi jälginud pikkade ja lühivormide esinemist. Süntaktilisi konstruktsioone esines minu materjalis viis tüüpi: verb tingivas kõneviisis + infinitiivivorm; verb tingivas 
kõneviisis + objekt; verb tingivas kõneviisis + öeldistäide; pealauses verb tingivas kõneviisis + kõrvallause; pealause + kõrvallause, milles verb on tingivas kõneviisis (mis on tingitud pealausest).

Tabeli igas lahtris on kaldkriipsuga eristatud esinemisjuhtude kogusagedus ja korrektsete esinemisjuhtude sagedus. Nii tähendab näiteks tabelis 4 veerus + INF esimeses reas 34 / 21, et B1-tasemel esines konstruktsioon verb ainsuse esimeses pöördes + infinitiiv 34 korral ning neist juhtudest olid 21 nii sisuliselt kui ka vormiliselt korrektsed. Esinemisjuhtude koguhulk on toodud viimases reas ja veerus. Kui esinemisjuhte on kokku viis või rohkem, on need eristatud poolpaksult ning vastavaid vorme ja konstruktsioone on tabeli järel lähemalt kirjeldatud.

TABEL 4. Isikulise tegumoe tingiva kõneviisi morfoloogilised vormid ja süntaktilised konstruktsioonid B1-taseme kirjalikus óppijakeeles

\begin{tabular}{|l|r|r|r|r|r|r|}
\hline \multicolumn{1}{|c|}{ VERB $_{\text {COND }}$} & + INF & + OBJ & + PRED & $\begin{array}{r}\text { + KÕRVAL- } \\
\text { LAUSE }\end{array}$ & PEALAUSE + & Kokku \\
\hline PR SG 1 PIKK & $34 / 21$ & $2 / 0$ & - & $2 / 0$ & $1 / 1$ & $\mathbf{3 9 / 2 2}$ \\
\hline PR SG 1 LÜHIKE & $9 / 7$ & - & - & - & - & $\mathbf{9} / \mathbf{7}$ \\
\hline PR SG 2 PIKK & $2 / 2$ & - & - & - & - & $2 / 2$ \\
\hline PR SG 3 & $10 / 10$ & $1 / 0$ & $4 / 4$ & - & - & $\mathbf{1 5 / 1 4}$ \\
\hline PR SG NEG & $1 / 1$ & - & - & - & - & $1 / 1$ \\
\hline PR PL 1 PIKK & $2 / 1$ & - & - & - & - & $2 / 1$ \\
\hline PR PL 2 PIKK & $2 / 1$ & - & - & - & - & $2 / 1$ \\
\hline PR PL 3 PIKK & $2 / 2$ & - & - & - & - & $2 / 2$ \\
\hline Kokku & $\mathbf{6 2 / 4 5}$ & $3 / 0$ & $4 / 4$ & $2 / 0$ & $1 / 1$ & $72 / 50$ \\
\hline
\end{tabular}


TABEL 5. Isikulise tegumoe tingiva kõneviisi morfoloogilised vormid ja süntaktilised konstruktsioonid B2-taseme kirjalikus óppijakeeles

\begin{tabular}{|c|c|c|c|c|c|c|}
\hline VERB $_{\text {COND }}$ & + INF & + OBJ & + PRED & $\begin{array}{l}+ \text { KõRVAL- } \\
\text { LAUSE }\end{array}$ & PEALAUSE + & Kokku \\
\hline PR SG 1 PIKK & 64 / 61 & $5 / 3$ & $1 / 1$ & $2 / 0$ & - & 72 / 65 \\
\hline $\begin{array}{l}\text { PR SG } 1 \\
\text { LÜHIKE }\end{array}$ & $9 / 6$ & - & $1 / 1$ & $2 / 0$ & - & $12 / 7$ \\
\hline PR SG 1 NEG & $1 / 0$ & - & - & - & - & $1 / 0$ \\
\hline PR SG 2 PIKK & $2 / 2$ & - & - & - & $1 / 0$ & $3 / 2$ \\
\hline $\begin{array}{l}\text { PR SG } 2 \\
\text { LÜHIKE }\end{array}$ & $4 / 4$ & - & - & - & $1 / 1$ & $5 / 5$ \\
\hline PR SG 3 & 89 / 86 & $1 / 0$ & $16 / 11$ & - & $4 / 3$ & $110 / 100$ \\
\hline PR PL 1 PIKK & $23 / 18$ & $3 / 1$ & - & $1 / 0$ & - & $27 / 19$ \\
\hline PR PL 2 PIKK & $4 / 3$ & $2 / 2$ & $2 / 2$ & - & $1 / 1$ & $9 / 8$ \\
\hline $\begin{array}{l}\text { PR PL } 2 \\
\text { LÜHIKE }\end{array}$ & - & - & $1 / 0$ & - & $1 / 1$ & $2 / 1$ \\
\hline PR PL 3 PIKK & $6 / 3$ & $2 / 1$ & - & - & - & $8 / 4$ \\
\hline $\begin{array}{l}\text { PR PL } 3 \\
\text { LÜHIKE }\end{array}$ & $2 / 2$ & - & - & - & $3 / 3$ & $5 / 5$ \\
\hline Kokku & $204 / 185$ & $13 / 7$ & $21 / 15$ & $5 / 0$ & $11 / 9$ & $254 / 216$ \\
\hline
\end{tabular}

B1-tasemel esines minu korpuses kokku 72 tingivas kõneviisis verbi ehk 0,3\% sõnede koguarvust, B2-tasemel oli tingivas kõneviisis verbe 254 ehk $1,2 \%$ sõnede koguarvust.

Morfoloogilistest vormidest esinesid nii B1- kui ka B2-tasemel ainult isikulise tegumoe olevikuvormid. B1-tasemel esines seejuures viis või rohkem korda kolm vormi, B2-tasemel kaheksa vormi. B1-tasemel esines enim ainsuse esimese pöörde pikki vorme (39 juhtu ehk 54,2\% tingiva kõneviisi kogujuhtudest, näide 1). Sageduselt teisel kohal olid ainsuse kolmanda pöörde vormid (15 juhtu ehk 20,8\%, näide 2). Üle viie korra esines ka ainsuse esimese pöörde lühivorme (9 juhtu ehk 12,5\% kogujuhtudest, näide 3). 
(1) Tahaksin teada veel maailmast.

(2) Sellg tuleks panna dressid spordi jalatsid ---

(3) Kui on võimalik tahaks väga edasi óppida.

Need kolm vormi esinesid üle viie korra ka B2-tasemel: ainsuse esimese pöörde pikki vorme esines 72 ehk $28,3 \%$ kogujuhtudest (4), ainsuse kolmanda pöörde vorme 110 ehk 43,3\% kogujuhtudest (5) ning ainsuse esimese pöörde lühivorme 12 ehk 4,7\% kogujuhtudest (6).

(4) Ma tutvusin ning tahaksin kirjutada oma arvamust.

(5) Oleks hea, et laps laindab oma silmaringi.

(6) Tahaks lepingu sõlmima kolmeks aastaks.

Lisaks esines B2-tasemel viis või rohkem korda viis morfoloogilist vormi. Ainsuses olid lisandunud teise pöörde lühivorm (5 juhtu ehk 2,0\%, näide 7). Kasutusel olid ka mitmuse vormid: esimese pöörde pikk vorm (27 juhtu ehk 10,6\% kogujuhtudest, näide 8), teise pöörde pikk vorm (9 juhtu ehk 3,5\%, näide 9), kolmanda pöörde pikk vorm (8 juhtu ehk $3,1 \%$, näide 10 ), ainsuse ja mitmuse kolmanda pöörde lühivorm (5 juhtu ehk 2,0\%, näide 11).

(7) Arvan, et sa võiks teda paluda ennast asendada.

(8) Me telliksime 5 viis pudelit šampust, kuus pudelit punase veini ja kus pudelit valge ---

(9) Mina oleksin väga tänulik Teile, kui Teie vastaksite minu küsimustele.

(10) Niissugusel puhul on vaja, et inimese ümbruses oleksid sellised inimesed, kes abistaksid talle, aitaksid eluraskusi ületada.

(11) --- et teisel sajandil ajalehted juba ei ole, oleks ainult internet, arvuti ja teised tehnoloogiat.

Seega on tingiva kõneviisi morfoloogiline keerukus B2-tasemel võrreldes B1-tasemega kasvanud.

Süntaktilistest konstruktsioonidest esines B1-tasemel viis või rohkem korda ainult üks: verb tingiva kõneviisi olevikus + infinitiiv (62 juhtu ehk 86,1\% kogujuhtudest, näide 12).

(12) Ma tahaksin sulle pakkuda üks pilet kontserdile Alla Pugatšovale. 
B2-tasemel esines viis või rohkem korda viis süntaktilist konstruktsiooni. Domineeriv oli seejuures samuti konstruktsioon verb tingiva kõneviisi olevikus + infinitiiv (204 juhtu ehk 80,3\% kogujuhtudest, näide 13). Lisaks esinesid ka konstruktsioonid verb tingiva kõneviisi olevikus + öeldistäide (21 juhtu ehk 8,3\%, näide 14) ja verb tingiva kõneviisi olevikus + objekt (13 juhtu ehk 5,1\%, näide 15).

(13) Sellepärast mul on kahju, et ma ei saa sind aidata, kuid ma võin anda nõu, mida sa võiksid teha.

(14) Ma tahan, et see päev oleks unustamatu.

(15) Me tahaksime uned riideid ---

Veel oli võrreldes B1-tasemega lisandunud tingiva kõneviisi kasutamine liitlauses: pealause + kõrvallauses verb tingiva kõneviisis olevikus (11 juhtu ehk 4,3\%, näide 16) ja pealauses verb tingivas kõneviisis olevikus + kõrvallause (5 juhtu ehk 2,0\%, näide 16).

(16) Sa palusid mind, et kirjutaksin sulle oma lapsepõlve.

(17) Ma hea meelega sooviksin et sa osalesid koolituses kutsu kedagi veel.

Seega on tingiva kõneviisi süntaktiline keerukus B2-tasemel kasvanud võrreldes B1-tasemega.

B1-tasemel esines kokku 50 tingiva kõneviisi sisuliselt ja vormiliselt korrektset kasutusjuhtu, mis on 70\% tingiva kõneviisi juhtude koguarvust. B2-tasemel esines 216 tingiva kõneviisi sisuliselt ja vormiliselt korrektset kasutusjuhtu, mis on 85\% tingiva kõneviisi juhtude koguarvust. Seega on tingiva kõneviisi kasutustäpsus B2-tasemel võrreldes B1-tasemega suurenenud.

\subsection{Tingiva kõneviisi esinemine B1- ja B2-taseme õppijakeeles verbide kaupa}

Edasi vaatlesin tingiva kõneviisi esinemist kummalgi tasemel esinevate verbide kaupa.

B1-tasemel esineb kaheksa tingivas kõneviisis olevat verbi: tahtma, saama, tulema, võima, pidama, olema, soovima, kirjutama. Neist 
esinevad sagedamini (viis või rohkem korda) kaks verbi: tahtma ja saama. B2-tasemel esineb tingivas kõneviisis kakskümmend kolm verbi: tahtma, soovima, võima, pidama, olema, soovitama, nõus olema, võtma, mängima, tellima, asendama, põhjendama, sõlmima, vastama, abistama, aitama, tegema, sobima, küsima, toimuma, laiendama, minema, saama. Neist esinevad sagedamini (viis või rohkem korda) kuus verbi: tahtma, olema, võima, pidama, soovima, soovitama.

Seega on tingiva kõneviisi leksikaalne keerukus B2-tasemel võrreldes B1-tasemega kasvanud.

Järgnevalt kirjeldan tingivas kõneviisis sagedamini esinevaid verbe detailsemalt: esitan iga verbi kohta sagedamad morfoloogilised vormid ja süntaktilised konstruktsioonid, milles ta esineb, ning suhtlusfunktsioonid, mida väljendab. Samuti kirjeldan esinemisjuhtude täpsust ning toon välja tüüpilised ebakorrektsused.

\subsubsection{Verb tahtma}

B1-tasemel esines kaks verbi tahtma morfoloogilist vormi: oleviku ainsuse esimese pöörde pikk vorm (18) ja oleviku ainsuse esimese pöörde lühivorm (19). Süntaktilistest konstruktsioonidest esines verb tingivas kõneviisis + infinitiiv (18-19).

(18) Tahaksin jutustada Teile huvitavast kursusest.

(19) Tahaks sind kontsertil kutsuda.

B2-tasemel esines kolm verbi tahtma morfoloogilist vormi: oleviku ainsuse esimese pöörde pikk vorm (20), oleviku ainsuse esimese pöörde lühivorm (21) ja oleviku mitmuse esimese pöörde pikk vorm (22). Süntaktilisi konstruktsioone esines B2-tasemel kaks: verb tingivas kõneviisis + infinitiiv (20-22) ja pealause (verb tingivas kõneviisis) + kõrvallause (23).

(20) Kõigepealt, tahaksin öelda, et see väide on pigem õige, kui vale.

(21) --- mina tahaks suhelda oma abikaasaga. 
(22) Hinna kohta tahaksime teada, et kas fotograafi teenused on hinnas või me peame temale eraldi maksma.

(23) Veel meie väga tähaksime et oleks inimene kes akkab sellega piduga tegelema.

Seega on verbi tahtma morfoloogiline ja süntaktiline keerukus B2-tasemel võrreldes B1-tasemega suurenenud.

Verbiga tahtma väljendati B1-tasemel kolme suhtlusfunktsiooni: tehti viisakas ettepanek, mis jätab ettepaneku saajale äraütlemisvõimaluse (24), väljendati enda soovi viisakas vormis (25) ja kommenteeriti viisakas vormis oma teksti loomisprotsessi (26).

(24) --- ma tahaksin sulle pakkuda minna sellel laupäeval kontserdile.

(25) Ma tahaksin midagi uut proovida.

(26) See oli nii huvitav ja ma tahaksin sellest kirjutada.

B2-tasemel väljendati verbiga tahtma samuti kolme suhtlusfunktsiooni: esitati viisakas küsimus (27), esitati viisakas soov (28), kommenteeriti viisakas vormis oma teksti loomisprotsessi (29).

(27) Ma tahaksin teada saada, kus te asute?

(28) Me tahaksime tähistada oma aastapäeva kahekümne üheksandal mail kell kaheksa õhtul.

(29) Veel, tahaksin liisada küsitluses tulemusi: ---

Seega ei ole suhtlusfunktsioonide väljendamise keerukus B2-tasemel võrreldes B1-tasemega suurenenud.

B1-tasemel esines verbi tahtma tingiva kõneviisi korrektseid kasutusjuhtusid 32 (71\% nende konstruktsioonide koguarvust) ja mittekorrektseid 13 (29\% nende konstruktsioonide koguarvust). Tüüpilised ebakorrektsused olid tingiva kõneviisi vormide tahaksin, tahaks vmt segiminek kindla kõneviisi minevikuvormidega tahtsin, olen tahtnud (30-31).

(30) --- see on minu unistus, ma alati tahaksin töötada suures firmas. * (olen tahtnud)

(31) Ma tahan sulle pakkuda üks pilet kontserdile. Ma tahaksin minna koos oma tuttavaga, aga kahjuks tema ei saa minna, ta on haige.* (tahtsin) 
B2-tasemel esines verbi tahtma tingiva kõneviisi korrektseid kasutusjuhtusid konstruktsiooni verb tingivas kõneviisis + infinitiiv puhul 66 (89\% nende konstruktsioonide koguarvust) ja mittekorrektseid 8 (11\% nende konstruktsioonide koguarvust). Konstruktsiooni pealause (verb tingivas kõneviisis) + kõrvallause korrektseid kasutusjuhtusid esines 1 (17\% nende konstruktsioonide koguarvust) ja mittekorrektseid 5 (83\% nende konstruktsioonide koguarvust). Tüüpiline ebakorrektsus oli kõrvallauses tingiva kõneviisi mittekasutamine (32-33).

(32) Ma tahaksin, et see ei võtnud palju aega, sest ma vajan teie teenust juba praegu.* (ei võtaks)

(33) Muidugi tahaks, et meie riigis üldse ei ole missugust prioriteeti. ${ }^{\star}$ (ei oleks)

Kokkuvõttes esines B2-tasemel korrektseid kasutusjuhte 67 (84\% koguarvust) ja mittekorrektseid 13 (16\% koguarvust). Seega on tingiva kõneviisi üldine kasutustäpsus B2-tasemel võrreldes B1-tasemega veidi tõusnud. Sealjuures võib märkida, et täpsus oli suurenenud neis konstruktsioonides, mida ka B1-tasemel juba kasutatakse. Konstruktsioonides, mis ilmusid alles B2-tasemel, oli täpsus väiksem.

\subsubsection{Verb olema}

B1-tasemel verbi olema tingivas kõneviisis ei esinenud. B2-tasemel esines üks verbi olema morfoloogiline tingiva kõneviisi vorm: oleviku kolmas pööre (34). Süntaktilisi konstruktsioone esines verbiga olema kaks: verb tingivas kõneviisis + öeldistäide (34) ja pealause + kõrvallause (verb tingivas kõneviisis) (35).

(34) Küll meie sinuga seda oskame aga minu meeles lisa koolitus oleks väga kasulik.

(35) Selleks ma mõtlen, et oleks väga tore korraldada konkurseid, tantsu ja mänge.

B2-tasemel väljendati verbiga olema kolme tähendust: esitati oletus (36), viisakas soov kirja saajale (37) või kaudne soov (38). 
(36) Arvan, et see koolitus oleks meie jaoks väga kasulik.

(37) Oleks hea, kui meil oli võimalus kuulata ansambel Trühvel.

(38) Võib olla me võiksime elada ilma konfliktideta? Oleks hea!

B2-tasemel esines verbi olema tingiva kõneviisi korrektseid kasutusjuhtusid 45 (73\% koguarvust) ja mittekorrektseid 17 (27\% koguarvust). Esines eri tüüpi kõrvalekaldeid, mille hulgast ei ole võimalik dominante välja tuua.

Verbi olema kasutamise keerukus on B2-tasemel võrreldes B1-tasemega suurenenud.

\subsubsection{Verb võima}

B1-tasemel verbi võima tingivas kõneviisis ei esinenud. B2-tasemel esines üks verbi võima morfoloogiline vorm, mitmuse esimene pööre (39), ja üks süntaktiline konstruktsioon: verb tingivas kõneviisis + infinitiiv (39). B2-tasemel väljendati verbiga võima üht suhtlusfunktsiooni: esitati viisakas ettepanek kirja saajale (39).

(39) Ma arvan, et meie võiksime osaleda sellel koolitusel.

B2-tasemel esines verbi võima tingiva kõneviisi korrektseid kasutusjuhtusid 16 (89\% koguarvust) ja mittekorrektseid 2 (11\% koguarvust). Domineerivat ebakorrektsust ei saa välja tuua.

Verbi võima kasutamise keerukus on B2-tasemel võrreldes B1-tasemega suurenenud.

\subsubsection{Verb pidama}

B1-tasemel verbi pidama tingivas kõneviisis ei esinenud. B2-tasemel esines kaks verbi pidama morfoloogilist vormi: ainsuse kolmas pööre (40) ja mitmuse kolmanda pöörde lühivorm (41) ning üks süntaktiline konstruktsioon: verb tingivas kõneviisis + infinitiiv (40-41). B2-tasemel väljendati verbiga võima üht suhtlusfunktsiooni: tegevuse kohustuslikkust (40-41). 
(40) Ja muidugi ma arvan, et tööpuuduse vähendamine peaks olema prioriteetiks kogu Euroopas.

(41) Edasi vastanud arvavad et riigieelarve prioriteet peaks olema lapsed,

B2-tasemel esines verbi pidama tingiva kõneviisi korrektseid kasutusjuhtusid 68 (97\% koguarvust) ja mittekorrektseid 2 (3\% koguarvust). Verbi pidama suur sagedus ja korrektsus olid tõenäoliselt mõjutatud ka ühe eksamiülesande sisendiks olnud küsimusest "Mis peaks olema Eesti riigieelarve prioriteet?".

Verbi pidama kasutamise keerukus on B2-tasemel võrreldes B1-tasemega suurenenud.

\subsubsection{Verb saama (modaalne)}

B1-tasemel esines üks verbi saama süntaktiline konstruktsioon: verb tingivas kõneviisis + infinitiiv (42). Domineerivaid morfoloogilisi vorme ega suhtlusfunktsioone verbi saama puhul B1-tasemel ei esinenud.

(42) Et ta on tubli naine, kes saaks kuuskümmend kilod ära viskata.

B2-tasemel verbi saama tingivas kõneviisis ei esinenud.

B1-tasemel esines verb saama tingiva kõneviisi korrektseid kasutusjuhtusid 4 (80\% koguarvust) ja mittekorrektseid 1 (20\% koguarvust). Domineerivaid eksimustüüpe ei saa välja tuua.

Verbi saama kasutamise keerukus on B2-tasemel võrreldes B1-tasemega vähenenud.

\subsubsection{Verb soovima}

B1-tasemel verbi soovima tingivas kõneviisis ei esinenud. B2-tasemel esines üks verbi soovima morfoloogiline vorm: ainsuse esimese pöörde pikk vorm (43) ja üks süntaktiline konstruktsioon: verb tingivas kõneviisis + infinitiiv (43). Verbiga võima väljendati B2-tasemel üht suhtlusfunktsiooni: esitati viisakas soov poolametlikus stiilis kirjas (43). 
(43) Ma sooviksin kindlustada oma korterit, ja lepingu sõlmimise pikkus on ---

B2-tasemel olid verbi soovima kõik kasutusjuhud korrektsed.

Verbi soovima kasutamise keerukus on B2-tasemel võrreldes B1-tasemega suurenenud.

\subsubsection{Verb soovitama}

B1-tasemel verbi soovitama tingivas kõneviisis ei esinenud. B2-tasemel esines verb soovitama ühes süntaktilises konstruktsioonis: verb tingivas kõneviisis + infinitiiv (44). Domineerivaid morfoloogilisi vorme ega suhtlusfunktsioone ei saa välja tuua.

(44) Ma soovitaksin sulle pöörduda Elenale.

B2-tasemel esines verbi soovitama tingiva kõneviisi korrektseid kasutusjuhtusid 1 (17\% koguarvust) ja mittekorrektseid 5 (83\% koguarvust). Tüüpiliseks ebakorrektsuseks oli B2-tasemel verbi soovitama kasutamine vales tähenduses verbi soovima asemel (45).

(45) Natuke vähem kolme protsenti võrra, soovitaksid saada infot internetist. $^{*}$ (sooviksid)

Verbi soovitama kasutamise keerukus on B2-tasemel võrreldes B1-tasemega suurenenud.

\subsection{Kokkuvõte}

Võrreldes B1-tasemega on tingiva kõneviisi kasutussagedus B2-tasemel suurem. Kui B1-tasemel esines tingivas kõneviisis verbe $0,3 \%$ kogu B1-korpuse sõnede arvust, siis B2-tasemel esines tingivas kõneviisis verbe 1,2\% kogu B2-korpuse sõnede arvust.

B2-tasemel on kasvanud ka tingiva kõneviisi kasutamise keerukus: a) on kasvanud tingivas kõneviisis esinevate eri verbide hulk, b) on kasvanud tingiva kõneviisi eri morfoloogiliste vormide hulk, c) on kasvanud tingiva kõneviisi süntaktiliste konstruktsioonide hulk. 
B1-tasemel esines tingivas kõneviisis kaheksa eri verbi, neist sagedamini (viis või rohkem korda) kaks eri verbi (tahtma, saama). B2-tasemel esines tingivas kõneviisis 23 eri verbi, neist sagedamini (viis või rohkem korda) kuus eri verbi (tahtma, olema, võima, pidama, soovima, soovitama).

B1-tasemel kasutati tingivat kõneviisi viis või rohkem korda kolmes eri morfoloogilises vormis (oleviku ainsuse esimese pöörde pikas vormis, oleviku ainsuse esimese pöörde lühivormis ja oleviku ainsuse kolmanda pöörde vormis). B2-tasemel kasutati tingivat kõneviisi viis või rohkem korda kaheksas eri morfoloogilises vormis (oleviku ainsuse esimese pöörde pikas vormis, oleviku ainsuse esimese pöörde lühivormis, oleviku ainsuse teise pöörde lühivormis, oleviku ainsuse kolmanda pöörde vormis, oleviku mitmuse esimese pöörde pikas vormis, oleviku mitmuse teise pöörde pikas vormis, oleviku mitmuse kolmanda pöörde pikas vormis, oleviku mitmuse kolmanda pöörde lühivormis).

B1-tasemel kasutati tingivat kõneviisi viis või rohkem korda ühes süntaktilises konstruktsioonis (verb tingiva kõneviisi olevikus + infinitiiv). B2-tasemel kasutati tingivat kõneviisi viis või rohkem korda viies eri süntaktilises konstruktsioonis (verb tingiva kõneviisi olevikus + infinitiiv, verb tingiva kõneviisi olevikus + objekt, verb tingiva kõneviisi olevikus + öeldistäide, pealause (verb tingiva kõneviisi olevikus) + kõrvallause, pealause + kõrvallause (verb tingiva kõneviisi olevikus).

Võrreldes B1-tasemega on B2-tasemel kasvanud tingiva kõneviisi kasutamise täpsus. Kui B1-tasemel oli kõigist tingiva kõneviisi kasutusjuhtudest nii sisuliselt kui ka vormiliselt korrektsed 71\%, siis B2-tasemel 84\%. B2-tasemel suurenes nende konstruktsioonide kasutustäpsus, mis esinesid ka B1-tasemel (verb tingivas kõneviisis + infinitiiv). B2-tasemel ilmuvate tingiva kõneviisi konstruktsioonide kasutustäpsus oli erisugune. Kõige ebakorrektsemalt kasutati konstruktsiooni pealause + kõrvallause (verb tingivas kõneviisis).

Suhtlusfunktsioonidest kasutati tingivat kõneviisi nii B1- kui ka B2-tasemel peamiselt viisakuse väljendamiseks. 


\section{Arutelu}

Uurimuses jälgisin tingiva kõneviisi kasutust eesti keele kui teise keele B1-taseme ja B2-taseme kirjalikes tekstides. Uurisin, kas ja kuidas muutub tingiva kõneviisi kasutamise keerukus (eri morfoloogiliste vormide, süntaktiliste konstruktsioonide, leksika ja suhtlusfunktsioonide väljendamise põhjal) ja täpsus (nii sisuliselt kui ka vormiliselt korrektsete kasutusjuhtude põhjal) ning otsisin tasemeid eristavaid deskriptoreid.

Selgus, et tingiva kõneviisi isikulise tegumoe olevikuvormid on kasutuses nii B1- kui ka B2-tasemel. Samas ei saa antud uurimuse põhjal öelda, millal need vormid eesti õppijakeelde ilmuvad, sest puuduvad andmed madalamate keeleoskustasemete kohta. Tingiva kõneviisi isikulise tegumoe minevikuvormid pole kasutuses ei B1- ega ka B2-tasemel. Samuti pole kummalgi tasemel kasutuses tingiva kõneviisi umbisikulisi vorme. Antud uurimuse põhjal ei saa öelda, kas ja millal need vormid õppijakeelde ilmuvad, sest puuduvad vastavad andmed kõrgemate keeleoskustasemete kohta.

Suhtlusfunktsioonidest kasutatakse tingivat kõneviisi nii B1- kui ka B2-tasemel peamiselt viisakuse väljendamiseks. Üldse ei kasutata B1- ega ka B2-tasemel tingivat kõneviisi teatud tingimustel toimuda võiva või toimuda võinud tegevuse kirjeldamiseks ja kahetsuse väljendamiseks.

Kokkuvõttes võib öelda, et tingiva kõneviisi kasutamine on üks B1- ja B2-keeleoskustaset eristav keeleline nähtus. B2-tasemel suureneb tingiva kõneviisi esinemissagedus, nende konstruktsioonide täpsus, mida ka B1-tasemel kasutatakse, ning keerukus. Tasemeid eristavateks deskriptoriteks võib pidada 1) tingiva kõneviisi kasutamist B2-tasemel suurema hulga eri verbidega kui B1-tasemel (sh suurema hulga mittetuumverbidega), 2) tingiva kõneviisi kasutamist B2-tasemel lisaks ainsuse esimese ja kolmanda pöörde vormidele ka teistes morfoloogilistes vormides, 3) konstruktsiooni verb tingivas kõneviisis + infinitiivivorm kõrval ka teiste konstruktsioonide esinemist (objektiga, öeldistäitega ja liitlause pea- ning kõrvallauses) B2-tasemel. 
Üldiselt kinnitab uurimus keeleoskuse lingvistilist arengut funktsionaalse taseme tõustes. Kui soome keele kohta on ilmnenud, et B1-tasemel suureneb eri keeleliste konstruktsioonide kasutussagedus ja B2-tasemel suureneb nende konstruktsioonide kasutuse korrektsus (Martin jt 2010), siis käesolev uurimus näitab, et tingiva kõneviisi puhul suureneb B2-tasemel eri konstruktsioonide kasutussagedus. Vajab edasist uurimist, kas sellise erinevuse põhjuseks võib olla ka keele omandamise viis: keelekeskkonnas keelt omandades võib eri konstruktsioonide hulk kasvada madalamal tasemel kui formaalõppes keelt õppides. Soome keele sarnane on B1-tasemel ilmnenud keelekonstruktsioonide korrektsuse suurenemine B2-tasemel, mis kinnitab, et korrektsuse saavutamiseks on vaja keelekonstruktsioone piisaval hulgal ise produtseerida.

Uurimus annab olulist infot eesti kirjaliku õppijakeele arengu kohta. Tingiva kõneviisi kasutuse osas tasuks järgnevalt uurida 1) tingiva kõneviisi esinemist A1-, A2- ja C1-tasemel; 2) tingiva kõneviisi esinemist emakeelekõnelejate kirjalikus keelekasutuses kvantitatiivselt; 3) tingiva kõneviisi esinemist keelekeskkonnas keelt omandanud õppijate keeles võrrelduna formaalses õppes omandanute keelega; 4) tingiva kõneviisi esinemist eri kasutajarühmade suulises keelekasutuses; 5) tingiva kõneviisi käsitlemist eesti keele kui teise keele õppematerjalides; 6) tingiva kõneviisi kasutust võrdlevalt teiste õppijakeeltega (nii lähisugulaskeelte, nagu soome, kui ka teistega).

Kindlasti on vajalik jätkata B1 - ja B2-keeletasemete lingvistilise sisu uurimist teiste keelenähtuste osas.

\section{Lühendid}

$\begin{array}{ll}\text { VERB }_{\text {COND }} & \text { verb tingivas kõneviisis } \\ + \text { INF } & \text { verb tingivas kõneviisis }+ \text { infinitiivivorm } \\ + \text { OBJ } & \text { verb tingivas kõneviisis }+ \text { objekt } \\ + \text { PRED } & \text { verb tingivas kõneviisis + öeldistäide } \\ + \text { KÕRVALLAUSE } & \text { pealauses verb tingivas kõneviisis + kõrvallause } \\ \text { PEALAUSE + } & \text { pealause + kõrvallause, milles verb tingivas kõneviisis } \\ \text { PR } & \text { olevik }\end{array}$




$\begin{array}{ll}\text { SG } & \text { ainsus } \\ \text { PL } & \text { mitmus } \\ 1 & \text { esimese pöörde vorm } \\ 2 & \text { teise pöörde vorm } \\ 3 & \text { kolmanda pöörde vorm } \\ \text { NEG } & \text { eituse vorm } \\ \text { PIKK } & \text { pikk vorm } \\ \text { LÜHIKE } & \text { lühivorm }\end{array}$

\section{Kirjandus}

Alanen, Riikka, Ari Huhta, Mirja Tarjanen 2010. Designing and assessing L2 writing tasks acrossing CEFR proficiency levels. - Inge Bartning, Maisa Martin, Ineke Vedder (Eds.). Communicative Proficiency and Linguistic Development: Intersections Between SLA and Language Testing Research. Eurosla Monographs Series 1. European Second Language Association, 21-56.

Argus, Reili 2004. Eesti keele käändesüsteemi omandamine: esimestest sõnadest miniparadigmadeni ['Acquisition of the Estonian case system: From first words to mini-paradigms']. - Emakeele Seltsi aastaraamat 49 (2003), 23-48.

Argus, Reili 2007. Eesti keele verbi ajamorfoloogia ja aspektilisuse omandamisest ['Acquisition of tense morphology and aspectuality in Estonian']. - Emakeele Seltsi aastaraamat 52 (2006), 1-20.

Argus, Reili 2012. Kausatiivsuse omandamisest eesti keeles ['Acquisition of causatives in Estonian']. - Eesti Rakenduslingvistika Ühingu aastaraamat 8, 5-20. http://dx.doi.org/10.5128/ERYa8.01

Bulté, Bram, Alex Housen 2012. Defining and operationalising L2 complexity: Dimensions of L2 performance and proficiency. - Alex Housen, Folkert Kuiken, Ineke Vedder (Eds.). Complexity, Accuracy and Fluency in SLA. Amsterdam-Philadelphia: John Benjamins, 21-46.

CEFLING. https://www.jyu.fi/hum/laitokset/kielet/tutkimus/hankkeet/paattyneet-hankkeet/cefling (10.7.2015).

CEFR = Euroopa keeleõppe raamdokument. Õppimine, õpetamine ja hindamine. Tartu: Haridus- ja Teadusministeerium, 2007.

Council of Europe. Education and Languages. Language Policy. http://www.coe. int/t/dg4/linguistic/DNR_EN.asp\#P66_9442 (10.7.2015).

Eesti keele käsiraamat ['Handbook of the Estonian Language']. http://www.eki.ee/ books/ekk09 (10.7.2015). 
Eesti vahekeele korpus ['Estonian Interlanguage Corpus']. http://evkk.tlu.ee (29.4.2014).

Ehala, Martin, Kristi Saarso, Silvi Vare, Jaan Õispuu 1997. Eesti keele suhtluslävi. Strasbourg: Council of Europe Publishing.

Ellis, Rod 2000. Form-Focussed Instruction and Second Language Learning Special Issue of Language Learning. Oxford: Blackwell.

Ellis, Rod 2008. The Study of Second Language Acquisition. Oxford: Oxford University Press.

English Grammar Profile. http://www.englishprofile.org/english-grammar-profile/grammar (10.7.2015).

English Vocabulary Profile. http://www.englishprofile.org/wordlists (10.7.2015).

Eslon, Pille 2011. Millest räägivad eesti õppijakeele käändeasendused? ['Implications of the Estonian learner language case replacements']. - Lähivõrdlusi. Lähivertailuja 21, 45-64. http://dx.doi.org/10.5128/LV21.02

Eslon, Pille 2012. Objekti ja tegevuse leksikaalne markeeritus õppijakeeles ['The lexical markedness of object and action in Estonian learner language']. Lähivõrdlusi. Lähivertailuja 22, 15-42. http://dx.doi.org/10.5128/LV22.01

Eslon, Pille 2013. Kahe keelekasutusvariandi võrdlus: morfoloogilised klassid ja klastrid ['The comparative study of language use: Morphological classes and clusters']. - Lähivõrdlusi. Lähivertailuja 23, 13-38. http://dx.doi. org/10.5128/LV23.01

Eslon, Pille 2014. Adverbi sisaldavate struktuuride tekstifunktsioonidest eesti ilukirjandus- ja õppijakeeles ['On the textual functions of adverbial structures in literary Estonian and in Estonian learner language']. - Lähivõrdlusi. Lähivertailuja 24, 15-46. http://dx.doi.org/10.5128/LV24.01

Gunnarsson, Cecilia 2012. The development of complexity, accuracy and fluency in the written production of L2 French. - Alex Housen, Folkert Kuiken, Ineke Vedder (Eds.). Dimensions of L2 Performance and Proficiency. Complexity, Accuracy and Fluency in SLA. Amsterdam-Philadelphia: Benjamins, 247-276.

Hausenberg, Anu-Reet, Marju Ilves, Annekatrin Kaivapalu, Krista Kerge, Katrin Kern, Mare Kitsnik, Ingrid Krall, Karin Rummo, Tiina Rüütmaa 2008. Iseseisev keelekasutaja. B1- ja B2-taseme eesti keele oskus. Tallinn: Riiklik Eksami- ja Kvalifikatsioonikeskus.

Hawkins, John A. 2004. Efficiency and Complexity in Grammars. Oxford: Oxford University Press. http://dx.doi.org/10.1093/acprof:oso/9780199252695. 001.0001 
Hawkins, John A., Paula Buttery 2009. Using Learner Language from Corpora to Profile Levels of Proficiency: Insights from the English Profile Programme. - L. Taylor, C. J. Weir (Eds.). Language Testing Matters: Investigating the Wider Social and Educational Impact of Assessment. Cambridge: Cambridge University Press, 158-175.

Hawkins, John A., Paula Buttery 2010. Criterial features in learner corpora: Theory and illustrations. - English Profile Journal, 1, e5. http://dx.doi.org/10.1017/ S2041536210000103

Housen, Alex, Folkert Kuiken 2009. Complexity, accuracy and fluency in second language acquisition. - Applied Linguistics 30 (4), 461-473. http://dx.doi. org/10.1093/applin/amp048

Housen, Alex, Folkert Kuiken, Ineke Vedder 2012. Complexity, accuracy and fluency. Definitions, measurement and research. - Alex Housen, Folkert Kuiken, Ineke Vedder (Eds.). Dimensions of L2 Performance and Proficiency. Complexity, Accuracy and Fluency in SLA. Amsterdam-Philadelphia: John Benjamins, 1-20.

Hulstijn, Jan H. 2011. Language proficiency in native and nonnative speakers: An agenda for research and suggestions for second-language assessment. Language Assessment Quarterly 8 (3), 229-249.

Hulstijn, Jan H. 2014. The Common European Framework of Reference for Languages: A challenge for applied linguists. - International Journal for Applied Linguistics 165 (1), 3-18. http://dx.doi.org/10.1075/itl.165.1.01hul

Ilves, Marju 2008. Algaja keelekasutaja. A2-taseme eesti keele oskus. Tallinn: Eesti Keele Sihtasutus.

Ilves, Marju 2010. Läbimurre. A1-taseme eesti keele oskus. Tallinn: Eesti Keele Sihtasutus.

Jarvis, Scott, Terence Odlin 2000. Morphological type, spatial reference, and language transfer. - Studies in Second Language Acquisition 22 (4), 535-556. http://dx.doi.org/10.1017/S0272263100004034

Kaivapalu, Annekatrin 2005. Lähdekieli kielenoppimisen apuna. Jyväskylä Studies in Humanities 44. Jyväskylä: Jyväskylän yliopisto.

Kerge, Krista 2001. Eesti süntaks keeleõppe praktikule: käsiraamat. Tallinn: TEA Kirjastus.

Kerge, Krista 2008. Vilunud keelekasutaja. C1-taseme eesti keele oskus. Tallinn: Eesti Keele Sihtasutus.

Kerge, Krista, Anne Uusen, Halliki Põlda 2014a. Teismeea loovkirjutiste sõnavara ja selle hindamine ['Teenage vocabulary and its assessment in creative 
writing']. - Eesti Rakenduslingvistika Ühingu aastaraamat 10, 157-175. http://dx.doi.org/10.5128/ERYa10.10

Kerge, Krista, Hille Pajupuu, Pilvi Alp, Anne Uusen 2014b. Towards sophisticated writing. - Krista Kerge (Ed.). Studies in Language Acquisition, Learning and Corpora. Proceedings of the Tallinn University Institute of Estonian Language and Culture 16. Tallinn: Tallinna Ülikool, 103-116.

Kitsnik, Mare 2014. Verbivormid B1- ja B2-taseme kirjalikus õppijakeeles ['Written learner language verb forms at B1 and B2 levels']. - Eesti ja soome-ugri keeleteaduse ajakiri / Journal of Estonian and Finno-Ugristic Linguistics 5 (3), 9-35.

Kitsnik, Mare 2007. Eesti keele kui teise keele õppija kõrvalekalded eituse väljendamisel ['Usage of negation in the Estonian interlanguage corpus']. - Pille Eslon (Toim.). Tallinna Ülikooli keelekorpuste optimaalsus, töötlemine ja kasutamine. Tallinna ülikooli eesti filoloogia toimetised 9. Tallinn: Tallinna Ülikool, 152-181.

Krashen, Stephen 1982. Principles in Second Language Acquisition. Pergamon Press.

Kuiken, Volkert, Ineke Vedder 2012. Syntactic complexity, lexical variation and accuracy as a function of task complexity and proficiency level in L2 writing and speaking. - Alex Housen, Folkert Kuiken, Ineke Vedder (Eds.). Dimensions of L2 Performance and Proficiency. Complexity, Accuracy and Fluency in SLA. Amsterdam-Philadelphia: Benjamins, 143-170.

Larsen-Freeman, Diane 1997. Chaos/complexity science and second language acquisition. - Applied Linguistics 18 (2), 141-165. http://dx.doi. org/10.1093/applin/18.2.141

Larsen-Freeman, Diane 2006. The emergence of complexity, fluency and accuracy in the oral and written production of five Chinese learners of English. Applied Linguistics 27 (4), 590-619. http://dx.doi.org/10.1093/applin/ aml029

Larsen-Freeman, Diane 2009. Adjusting expectations: The study of complexity, accuracy and fluency in second language acquisition. - Applied Linguistics 30 (4), 579-589. http://dx.doi.org/10.1093/applin/amp043

Larsen-Freeman, Diane 2011. A complexity approach to second language development / acquisition. - Dwight Atkinson (Ed.). Alternative Approaches to Second Language Acquisition. Routledge, 48-72.

Long, Michael 1996. The role of the linguistic environment in second language acquisition. - William Ritchie, Tej Bhatia (Eds.). Handbook of Second Language Acquisition. San Diego: Academic Press, 413-468. 
MacWhinney, Brian 2004. A unified model of language acquisition. - J. Kroll, A. De Groot (Eds.). Handbook of Bilingualism: Psycholinguistic Approaches. Oxford University Press, 49-67.

Maisla, Diana 2014. Eesti keele mineviku ajavormid vene emakeelega üliõpilaste kasutuses ['Past tenses of Estonian language in the usage of Russian-speaking students']. Dissertationes philologicae estonicae Universitatis Tartuensis 20. Tartu: Tartu Ülikooli Kirjastus.

Martin, Maisa, Sanna Mustonen, Niina Reiman, Marja Seilonen 2010. On becoming an idependent user. - Inge Bartning, Maisa Martin, InekeVedder (Eds.). Communicative Proficiency and Linguistic Development: Intersections Between SLA and Language Testing Research. Eurosla Monographs Series 1. European Second Language Association, 57-80.

Metslang, Helle 1999. Is the Estonian and Finnish conditional actually a conditional? - Mati Erelt (Ed.). Estonian: Typological studies III. Publications of the Department of Estonian of the University of Tartu. Tartu: Tartu University Press, 97-127.

Metslang, Helle, Ingrid Krall, Renate Pajusalu, Kristi Saarso, Elle Sõrmus, Silvi Vare 2003. Keelehärm: eesti keele probleemseid piirkondi. Tallinn: Tallinna Pedagoogikaülikool.

Norris, John M., Lourdes Ortega 2009. Towards an organic approach to investigating CAF in instructed SLA: The case of complexity. - Applied Linguistics 30 (4), 555-578. http://dx.doi.org/10.1093/applin/amp044

North, Brian 2014. The CEFR in Practise. English Profile Studies 4. Cambridge University Press.

O’Donnell, Mick 2013. From learner corpora to curriculum design: An empirical approach to stagong the teaching of grammatical concepts. - Procedia Social and Behavioral Scienses 95, 571-580.

Pajusalu, Karl, Renate Pajusalu 2004. The conditional in everyday Estonian: It's form and functions. - Linguistica Uralica 4, 257-269.

Pajusalu, Renate 2014. Palved eesti, soome ja vene keeles: grammatika pragmaatika teenistuses ['Requests in Estonian, Finnish and Russian: grammar and pragmatics']. - Eesti Rakenduslingvistika Ühingu aastaraamat 10, 241-257. http://dx.doi.org/10.5128/ERYa10.15

Pajusalu, Renate, Karl Pajusalu 2010. Konditsionaal relatiivlauses ['Conditional in relative clauses']. - Eesti ja soome-ugri keeleteaduse ajakiri / Journal of Estonian and Finno-Ugric Linguistics 1 (2), 243-254.

Pajusalu, Renate, Pirjo Tõugu, Maigi Vija, Tiia Tulviste 2011. Konditsionaali omandamisest eesti lapsekeeles ['The acquisition of the Estonian conditional 
in child language']. - Eesti Rakenduslingvistika Ühingu aastaraamat 7, 279-296. http://dx.doi.org/10.5128/ERYa7.09

Pallotti, Gabriele 2009. CAF: Defining, refining and differentiating constructs. Applied Linguistics 30 (4), 590-601. http://dx.doi.org/10.1093/applin/ amp045

Pastuhhova, Olga 2005. Interferentsivead vene üliõpilaste suulise ja kirjaliku eesti keele süntaksis. - Raili Pool (Toim.). Teine keel. Tartu Ülikooli eesti keele (võõrkeelena) õppetooli toimetised 5. Tartu: Tartu Ülikooli Kirjastus, 75-110.

Pastuhhova, Olga 2011. Kirjaliku produtseerimisprotsessi uurimise võimalused programmi ScriptLog abil: Juhtumiuuring ['Research on the writing process using ScriptLog: A case study']. - Lähivõrdlusi. Lähivertailuja 21, 185-212. http://dx.doi.org/10.5128/LV21.08

Pienemann, Manfred 1998. Language Processing and Second Language Development. Processability Theory. Amsterdam: John Benjamins. http://dx.doi. org/10.1075/sibil.15

Plado, Helen 2013. Eesti keele otstarbelausest ['Estonian clause of purpose']. - Keel ja Kirjandus 4, 269-284.

Pool, Raili 2007. Eesti keele teise keelena omandamise seaduspärasusi täis- ja osasihitise näitel ['The acquisition of total and partial objects by learners of Estonian as a second language']. Dissertationes philologicae estonicae Universitatis Tartuensis 19. Tartu: Tartu Ülikooli Kirjastus.

Pool, Raili 2010. Eesti keele teise keelena uurimine Tartu Ülikoolis - hetkeseis ja perspektiivid ['Research at the University of Tartu as a second language: Present situation and future prospects']. - Eesti ja soome-ugri keeleteaduse ajakiri / Journal of Estonian and Finno-Ugric Linguistics 1 (1), 5-19.

Profile deutsch. https://www.goethe.de/de/spr/unt/kum/prd.html (10.7.2015).

Ratassepp, Maria 2005. Vene abiturientide vead eesti keele verbirektsioonis. - Raili Pool (Toim.). Teine keel. Tartu Ülikooli eesti keele (võõrkeelena) õppetooli toimetised 5. Tartu: Tartu Ülikooli Kirjastus, 111-134.

Ringbom, Håkan 2007. Cross-Linguistic Similarity in Foreign Language Learning. Clevedon: Multilingual Matters LTD.

Rüütmaa, Tiina 2014. Kontrastiivne ülevaade kõneviisisüsteemist ungari ja eesti kõrvallauses ['Mood System in the Hungarian and Estonian Subordinate Clause']. Dissertationes philologicae uralicae Universitatis Tartuensis 13. Tartu: Tartu Ülikooli Kirjastus.

Salamoura, Angeliki, Nick Saville 2010. Exemplifying the CEFR: Criterial features of written learner English from the English profile programme. - Inge 
Bartning, Maisa Martin, InekeVedder (Eds.). Communicative Proficiency and Linguistic Development: Intersections Between SLA and Language Testing Research. Eurosla Monographs Series 1. European Second Language Association, 101-132.

Simple Concordancer. http://softadvice.informer.com/Simple_Concordance_ Programme.html (10.7.2015).

Skehan, Peter 1998. A Cognitive Approach to Language Learning. Oxford: Oxford University Press.

Skehan, Peter 2003. Task-based instruction. - Language Teaching 36 (1), 1-14. http://dx.doi.org/10.1017/S026144480200188X

Skehan, Peter 2009. Modelling second language performance: Integrating complexity, accuracy, fluency and lexis. - Applied Linguistics 30 (4), 510-532. http://dx.doi.org/10.1093/applin/amp047

Spoelman, Marianne, Marjolijn Verspoor 2010. Dynamic patterns in development of accuracy and complexity: A longitudinal case study in the acquisition of Finnish. - Applied Linguistics 31 (4), 532-553. http://dx.doi.org/10.1093/ applin/amq001

Teemets, Helena 2010. Ettepanekute ja pakkumiste väljendamine eesti argidialoogides ['Formulation of propsitions, offers and their answers in everyday dialogues']. Bakalaureusetöö. Tartu: Tartu ülikool. http://www.murre.ut.ee/ arhiiv/naita_pilt.php?materjal=kasikiri\&materjal_id=D1610\&sari=D (10.7.2015).

TOPLING. https://www.jyu.fi/hum/laitokset/kielet/tutkimus/hankkeet/topling (10.7.2015). 


\title{
The conditional mood as an indicator of increased language competence in Estonian B1 and B2 level written learner language
}

\author{
MARE KITSNIK \\ Tallinn University
}

The article described the use of the conditional mood in written exam texts of adult second language learners of Estonian at B1 and B2 level. The study on which the article is based is part of a larger study, the goal of which is to develop linguistic descriptions to accompany the functional descriptions of B1 and B2 level given in the Common European Framework of Reference for Languages (CEFR 2007). This is to be achieved by identifying the linguistic categories typically used at these levels, describing their frequency of use, analyzing their complexity and accuracy (Housen et al. 2012), determining the connections between the categories and various discourse functions, and specifying descriptors that serve to distinguish between the two levels.

As the conditional mood is used far more at B2 level than at B1 level (Kitsnik 2014), it is one of the categories distinguishing $B 2$ from $B 1$ which requires more detailed study. The results of the study discussed in the article show that at both B1 and B2 level, only the personal voice present tense forms of the conditional mood are used. At B1 level, the conditional is used with eight different verbs, most frequently tahtma 'to want' and saama 'be able to'. At B2 level, the conditional is used with 23 different verbs, most often with tahtma 'to want', olema 'to be', võima 'to be able to', pidama 'must', soovima 'to wish, desire', and soovitama 'to recommend'.

At B2 level, the conditional is used in more morphological forms than those found at B1 level (the first and third person singular), and it also appears in a range of other constructions (with an object, with a predicate, and in both the main and subordinate clauses of complex sentences) in addition to the B1-level construction of "verb in conditional + infinitive". As regards discourse functions, the conditional is used at both B1 and B2 level primarily to express 
politeness. Linguistic accuracy increases at B2 level in the constructions which are used also at B1 level.

Keywords: second language acquisition; morphosyntax; lexicon; frequency; accuracy; complexity

\section{Mare Kitsnik}

Tallinna Ülikooli humanitaarteaduste instituut Narva mnt 25

10120 Tallinn, Estonia

marekitsnik@gmail.com 